\title{
PTEN in Regulating Hematopoiesis and Leukemogenesis
}

\author{
Yilin $\mathrm{Wu},{ }^{1,2}$ Haichuan $\mathrm{Zhu},{ }^{1,2}$ and Hong $\mathrm{Wu}^{1}$ \\ ${ }^{1}$ The MOE Key Laboratory of Cell Proliferation and Differentiation, School of Life Sciences, \\ Peking-Tsinghua Center for Life Sciences, Beijing Advanced Innovation Center for Genomics, \\ Peking University, Beijing 100871, China \\ Correspondence: hongwu@pku.edu.cn
}

PTEN is one of the most frequently mutated tumor suppressor genes in human cancers. By counteracting the PI3K/AKT/mTOR pathway, PTEN plays an essential role in regulating hematopoietic stem cells (HSCs) self-renewal, migration, lineage commitment, and differentiation. PTEN also plays important roles in suppressing leukemogenesis, especially T-cell acute lymphoblastic leukemia (T-ALL). Herein, we will review the function of PTEN in regulating hematopoiesis and leukemogenesis and discuss potential therapeutic approaches against leukemia with PTEN mutations.

$P^{1}$ TEN (phosphatase and tensin homolog deleted on chromosome 10, also named MMAC1 and TEP1), was identified as a tumor suppressor gene by three independent groups in 1997 (Li and Sun 1997; Li et al. 1997; Steck et al. 1997). As the second most frequently mutated tumor suppressor gene, PTEN is located on chromosome 10q23, a hotspot for deletions and mutations found in 15 or more human cancer types (Bailey et al. 2018). Germline mutations of PTEN are associated with hereditary cancer predisposition syndromes, such as Cowden disease and Bannayan-Zonana syndrome, with an elevated incidence of breast and thyroid cancers (Liaw et al. 1997; Nelen et al. 1997).

The protein product of $P T E N$ possesses both lipid and protein phosphatase activities, as well as phosphatase-independent activities (Worby and Dixon 2014). The most well-studied

PTEN functions rely on its lipid phosphatase activity by counteracting the PI3K/AKT/ mTOR signaling pathway. PTEN regulates a plethora of cellular functions, ranging from stem cell self-renewal and genomic integrity to cell proliferation, survival, metabolism, and migration (for review, see Stiles et al. 2004; Song et al. 2012). Over the past 20 years, various genetic and genomic approaches have led to a comprehensive view on the roles of PTEN in regulating hematopoiesis and leukemia/lymphoma development.

Hematopoiesis is vital for all mammals; it plays essential roles in transporting nutrients, removing wastes, and preventing infections. Hematopoiesis produces billions of mature blood cells of multilineages daily to maintain blood circulation and homeostasis. In responding to infections, emergencies as well as hematopoietic

\footnotetext{
${ }^{2}$ These authors contributed equally to this work.

Editors: Charis Eng, Joanne Ngeow, and Vuk Stambolic

Additional Perspectives on The PTEN Family available at www.perspectivesinmedicine.org

Copyright $\odot 2020$ Cold Spring Harbor Laboratory Press; all rights reserved; doi: 10.1101/cshperspect.a036244

Cite this article as Cold Spring Harb Perspect Med 2020;10:a036244
} 
Y. Wu et al.

malignancies, increasing in a specific lineage $(\mathrm{s})$ of blood cells are often observed (Wilson et al. 2008; Essers et al. 2009; Baldridge et al. 2010; Takizawa et al. 2012).

The hematopoietic stem cells (HSCs) are the common ancestor of all blood cell types. HSCs can self-renew and differentiate into all blood lineages (Weissman 2000). Although the concept of HSCs was developed in the late 19th century, the existence of HSCs, with the capacity of reconstituting all blood lineages in lethally irradiated recipients, was experimentally demonstrated much later (Till and McCulloch 1961; Becker et al. 1963). In the following decades, a hierarchy map was developed, illustrating a stepwise differentiation process from HSCs to mature blood cells. The long-term HSC (LT-HSC) resides at the top of the hierarchy (Smith et al. 1991; Osawa et al. 1996; Christensen and Weissman 2001), which can transit to short-term HSCs (ST-HSCs) with lower self-renewal capacity (Morrison et al. 1997; Yang et al. 2005). Multilineage progenitor cells are generated after losing some lineage potentials, such as lymphoidprimed multipotent progenitors (LMPPs) that preferentially produce lymphoid lineages, followed by single lineage-specific progenitors, such as CFU-E for red blood cell lineage (Adolfsson et al. 2001, 2005; Forsberg et al. 2006; Boyer et al. 2011). As summarized in this review, PTEN plays an essential role in regulating selfrenewal, migration, lineage commitment, and differentiation of HSCs.

Related to the essential roles of PTEN in regulating HSCs and hematopoiesis, PTEN mutations have been found in human leukemias and lymphomas, especially in T-cell acute lymphoblastic leukemia (T-ALL). The availability of small-molecule inhibitors against the PTENcontrolled PI3K-AKT-mTOR pathway has provided new therapeutic opportunities for treating those leukemias and lymphomas with PTEN mutations.

\section{PTEN IN REGULATING HEMATOPOIESIS}

Most of our knowledge on the roles of PTEN in regulating hematopoiesis comes from genetically engineered mouse models, of which the mu- rine homolog Pten is deleted at a specific hematopoietic stage or in a specific lineage using the Cre-Loxp system. Table 1 summarizes the published Pten hematopoietic-specific deleted lines and their associated phenotypes.

\section{PTEN Controls HSC Self-Renewal}

The role of PTEN in negatively regulating somatic stem cell proliferation and survival was first reported when Pten was deleted in the neural stem cells in vivo (Groszer et al. 2001). Subsequent analyses using in vitro neurosphere culture further demonstrated that PTEN negatively regulates neural stem cell self-renewal by modulating its $G_{0}-G_{1}$ cell-cycle entry and growth factor dependency (Groszer et al. 2006). Although these findings are interesting and important, the in vivo proof for the role of PTEN in regulating stem cell self-renewal is lacking because of the limitations of the neural stem cell system.

HSC is the most well-established somatic stem cell system where stem cell self-renewal can be easily and more definitively studied in vivo (Weissman et al. 2001). pIpC-inducible $\mathrm{Mx}$-1-Cre line was first used to study the role of PTEN in adult HSCs (Yilmaz et al. 2006; Zhang et al. 2006). PTEN loss indeed drives quiescent LT-HSCs entering cell cycle, leaving the bone marrow niche and accumulating in the spleen. Pten-null HSCs in this model lose their ability for long-term reconstitution after transplantation and are eventually depleted. The above-mentioned phenotypes can be rescued by rapamycin treatment, suggesting that constitutive mTOR activation has a detrimental effect on HSC stemness maintenance (Yilmaz et al. 2006). Mechanistically, mTOR activation can induce aberrantly high rates of protein synthesis, which contributes to impaired Pten-null HSC self-renewal (Signer et al. 2014).

The FOXO family of transcription factors, which are downstream effectors of the PI3KAKT pathway, are known to be important for maintaining the HSC pool by eliminating reactive oxygen species (ROS) (Tothova et al. 2007). However, Pten-null HSC depletion is not due to ROS, but rather by mTOR-regulated p53 
PTEN in Hematopoiesis and Leukemogenesis
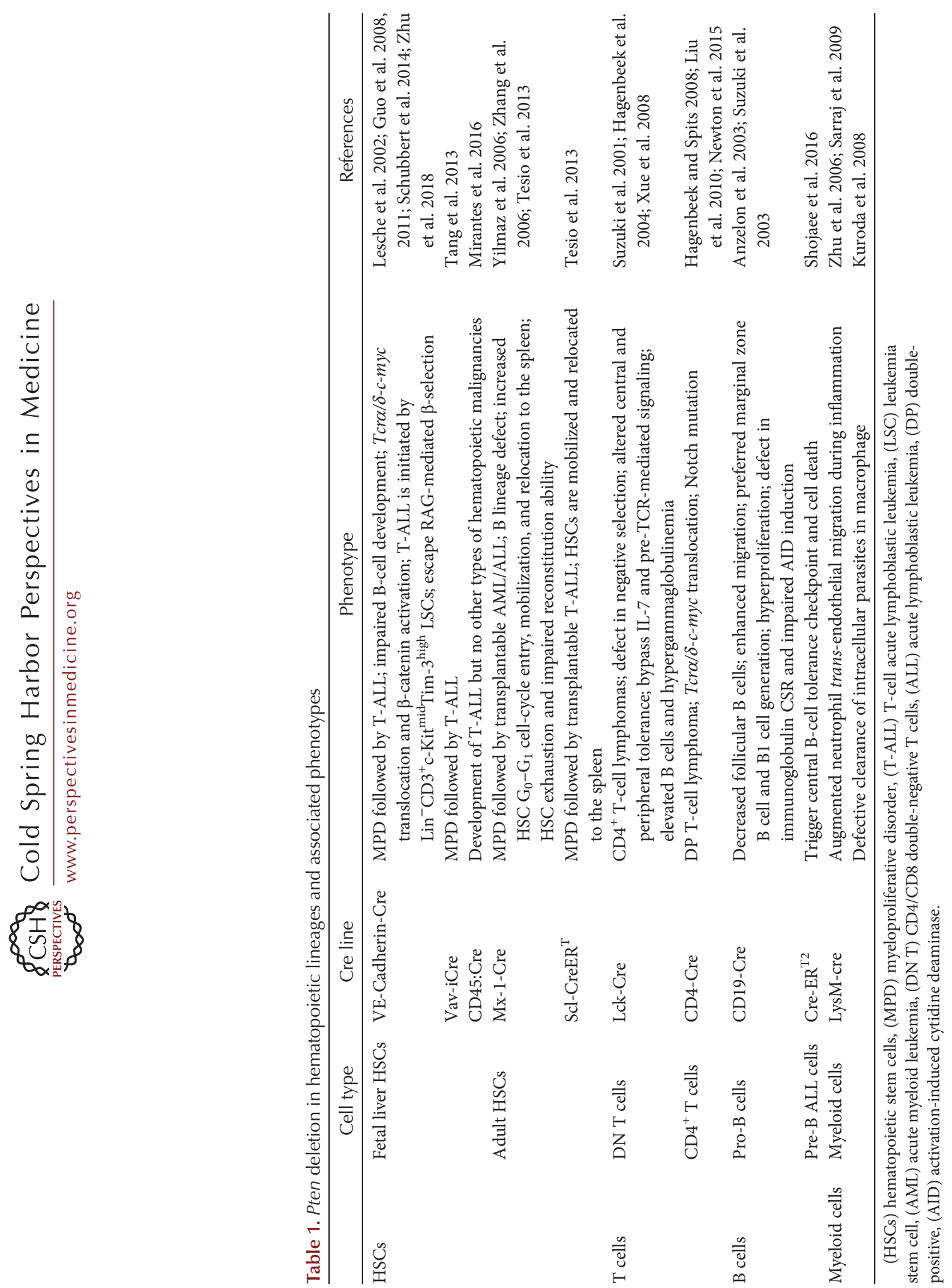
Y. Wu et al.

and $\mathrm{p} 16^{\text {Ink4a }}$ expression. Deletion of $\mathrm{p} 16^{\text {Ink4a }}$, $\mathrm{p} 16^{\text {Ink4a }} / \mathrm{p} 19^{\text {Arf }}$, or $\mathrm{p} 53$ (but not $19^{\text {Arf }}$ ) can rescue the reconstitution capacity of Pten-null HSCs (Lee et al. 2010). mTOR exists in two distinct functional complexes, mTORC1 and mTORC2. mTORC1 controls cell proliferation and growth by activating downstream S6 kinase and mTORC2 directly phosphorylates and thereby activates AKT (Guertin and Sabatini 2007). Further genetic studies show that both mTORC1 and mTORC2 play nonredundant roles in phenotypes associated with Pten deletion (Kalaitzidis et al. 2012; Magee et al. 2012). In addition, inactivation of mTORC2 abrogates Pten-null HSCs phenotype in adult, but not in neonatal mice, indicating that PTEN/mTORC2 signaling axis functions in HSCs in a temporally dependent manner (Magee et al. 2012).

The $\mathrm{Mx}-1-\mathrm{Cre}$ is a very powerful tool for pIpC-inducible gene deletion. However, Mx-1Cre is not only expressed in HSCs but also in other hematopoietic cells and tissues (www.jax .org/strain/002527). PTEN loss in those cell types may send a paracrine signal to HSCs, complicating the phenotype analysis. pIpC-induced interferon (IFN) $\alpha$ can also promote dormant HSCs to enter the cell cycle (Essers et al. 2009), which may synergize with the effect of PTEN loss on HSCs. To circumvent these issues, a fetal liver HSC specifically expressed VE-Cadherin-Cre (VE-Cad-Cre) line was used (Guo et al. 2008). Fetal liver Pten deletion does not cause HSC exhaustion in adults (unpubl.). Similarly, tamoxifen (Tx)-inducible Scl-CreERT (Scl-Cre)-mediated Pten deletion in adult HSCs shows no HSC exhaustion either (Tesio et al. 2013).

The differences seen in Mx-1-Cre versus VE-Cad-Cre or Scl-Cre-mediated Pten HSC deletions could be a result of the nature of Cre lines used or the impacts of genetic background (Freeman et al. 2006). Besides IFN- $\alpha$ induced HSC activation, high levels of G-CSF secreted by Pten-deficient myeloid cells can mobilize HSCs from the bone marrow to the spleen, suggesting that a non-cell-autonomous mechanism may contribute to HSC mobilization in Ptennull models (Tesio et al. 2013). Yet other studies argue that PTEN-modulated HSC cell-cell con- tacts or response to inflammatory cytokines plays more important roles in HSC mobility (Li et al. 2016; Porter et al. 2016).

\section{PTEN Controls HSC Lineage Commitment and Functions}

Pten deletion in both fetal liver and adult HSCs leads to increased myeloid and $\mathrm{T}$ lineages, accompanied by decreased common lymphoid progenitors (CLPs) and arrested B-cell development (Zhang et al. 2006; Guo et al. 2008). Competitive reconstitution assay also prove that Pten-deficient HSCs have altered lineage potential. However, it is not clear whether the alterations seen in the T, B, and myeloid lineages are separate events or the result of an intrinsically linked control mechanism. A recent study demonstrates that PTEN loss in the HSC can lead to up-regulated Spil transcription factor expression in early $\mathrm{T}$ progenitors (ETPs), before Tcell commitment (Zhu et al. 2018). Because SPI1 plays an essential role in regulating HSCs and different hematopoietic lineages (Rothenberg et al. 2016), it may serve as the central node for PTEN-regulated lineage commitment.

\section{T-Cell Lineage}

The $\mathrm{T}$ lineage commitment starts from ETPs in the bone marrow, and then migrates into the thymic cortex. Within the thymus, multistep T-cell proliferation and differentiation occur temporally and spatially, including T-cell commitment, $\operatorname{Tcr} \beta$ locus rearrangement, $\beta$-selection, Tcr $\alpha$ locus rearrangement, and negative/positive selections. PTEN plays essential roles in almost every step of T-cell development and PTEN loss leads to T-cell lymphoma, T-ALL, and T-cell autoreactivity.

Pten deletion in HSCs leads to T-ALL development with $100 \%$ penetration (Guo et al. 2008; Tesio et al. 2013). In the VE-Cad-Cre; Pten ${ }^{L / L}$ model, PTEN loss leads to premature $\operatorname{Tcr} \beta$ locus rearrangement and enables $\mathrm{Rag1}^{-1-} \mathrm{T}$ cells bypassing $\beta$-selection to differentiate to doublepositive (DP) cells (Guo et al. 2011; Zhu et al. 2018). PTEN loss or PI3K activation provides sufficient nutrients to meet the needs of T-cell 
differentiation from the double-negative (DN) to DP stage and mTOR serves as a critical signaling mediator for this process (Guo et al. 2011). Similarly, Pten deletion in DN (LckCre) or $\mathrm{CD}^{+} \mathrm{T}$ cells (CD4-Cre) leads to DP $\mathrm{T}$-cell lymphomas, and T-cell development in these models can also bypass RAG-mediated $\beta$-selection as well as the requirements of IL-7 and pre-TCR-mediated signaling (Hagenbeek et al. 2004; Hagenbeek and Spits 2008; Liu et al. 2010). These results suggest that constitutive activation of the PI3K/AKT/mTOR pathway can send an "inside-out" signal and promote T-cell differentiation in the absence of the "outside-in" signaling from the pre-TCR complex.

Pten heterozygous mice with one allele of Pten T-cell-specific deleted show spontaneous activation of $\mathrm{CD}^{+}{ }^{+} \mathrm{T}$ cells, defects in negative selection during development, as well as central and peripheral tolerance, suggesting that PTEN is an important regulator for T-cell homeostasis and self-tolerance (Suzuki et al. 2001). Interestingly, this model also shows increased B cells and hypergammaglobulinemia, a phenotype not reported in other T-cell-specific Pten deletion models (Table 1), suggesting that this phenotype may be contributed by the Pten heterozygous environment rather than Pten-deficient T cells.

\section{$B$-Cell Lineage}

Similar to T-cell, B-cell development also undergoes a multistep process, including prepro$B$, pro- $B$, pre- $B$, immature $B$, and $B$ cells with several checkpoints (for review, see Melchers 2015). Pten deletion in both fetal liver and adult HSCs leads to decreased CLPs, arrested B-cell development after prepro-B progenitor stage, and lost white pulp in the spleen (Zhang et al. 2006; Guo et al. 2008). The mechanism underlying PTEN-controlled B-lineage commitment and differentiation is currently unknown but blocking leukemia stem cell (LSC) maintenance and T-ALL development in the VE-Cad-Cre; $P_{t e n}{ }^{L / L}$ model can restore white pulp in the spleen, suggesting a potential link between prepro-B progenitors and T-ALL LSC formation and function (Zhu et al. 2018).
CD19 is a cell-surface protein expressed specifically in $\mathrm{B}$ lineage from pro-B to mature $\mathrm{B}$ stages. CD19-Cre-mediated Pten deletion can substitute the function of CD19 and rescue B1 and marginal zone B-cell formation in $\mathrm{Cd} 19^{-/-}$ mice (Anzelon et al. 2003). Pten-deficient B cells are hyperproliferative and resistant to apoptotic stimuli. Immunoglobulin class switch recombination is defective, suggesting that PTEN plays an important role in B-cell development and homeostasis (Suzuki et al. 2003).

Studies on the role of PTEN in pre-B-ALL suggest that PTEN is a critical gatekeeper of Bcell tolerance, which is known to be controlled by an intermediate level of PI3K signaling. PTEN loss in pre-B-ALL leads to cell death (Shojaee et al. 2016). PI3K also controls the activities of the FOXO family of transcription factors. Selective Foxo1 deletion at different B-cell developmental stages leads to early B-cell development blockade (Suzuki et al. 2003; Dengler et al. 2008). These results collectively indicated that PTEN is essential for B-cell homeostasis, including B-cell commitment, development, and maturation following stimulation.

\section{Myeloid Lineage}

Pten deletion in both the fetal liver and adult HSCs leads to myeloproliferative disorder (MPD) (Zhang et al. 2006; Guo et al. 2008). However, it is not clear whether MPD is the precursor of acute myeloid leukemia (AML) observed in the Mx-1-Cre-mediated Pten deletion model (Yilmaz et al. 2006) because MPD phenotypes are present in VE-Cad-Cre and Scl-Cre Pten models without AML development (Guo et al. 2008; Tesio et al. 2013).

The PTEN-C/EBPA-CTNNA1 signaling axis, which is evolutionarily conserved in humans, mice, and zebrafish, may contribute to the expansion of myeloid lineage and transformation of HSCs and myeloid progenitors ( Fu et al. 2010). Pten deletion causes up-regulation of the PI3K pathway in the myeloid cells, which secrete high levels of G-CSF and stimulate myeloid progenitor cell proliferation (Tesio et al. 2013). Furthermore, mice with macrophage Pten deletion have reduced the ability to elimi- 
Y. Wu et al.

nate parasites (Kuroda et al. 2008) while Ptendeleted neutrophils have enhanced invasive ability and can be readily recruited to inflamed sites (Sarraj et al. 2009).

\section{PTEN IN REGULATING LEUKEMOGENESIS}

\section{PTEN Deletion and Mutations in Human} Leukemia and Lymphomas

PTEN is functionally lost in a range of human cancers through mutation, deletion, transcriptional silencing, and protein inactivation (Salmena et al. 2008). PTEN mutation or deletion have been found in hematological malignancies but with much lower frequencies, as compared to that of solid tumors (Hollander et al. 2011). Among all hematopoietic malignancies, T-ALL has the highest rates of PTEN deletion or mutation, while few or no PTEN deletion/mutations have been reported in AML and B-ALL, respectively (see Fig. 1). PTEN deletions or mutations are also found in T-cell lymphomas and large B-cell lymphomas (Fig. 1).

The high PTEN mutation frequency in T-ALL and T-cell lymphomas is probably related to the essential role of PTEN or PI3K pathways in T-cell lineage commitment and differentiation, as discussed in the above section. The reason for low mutation rate in AML is currently unknown but may relate to increased SPI1 levels in the PTEN-null early progenitors (unpubl.) as Spi1 knockout or decreased expression is known to associate with AML (Verbiest et al. 2015). Bcell tolerance is controlled by an intermediate level of PI3K signaling. PTEN loss in pre-BALL leads to hyperactivated PI3K signaling and consequently cell death, which may explain the undetectable PTEN mutations in B-ALL (Shojaee et al. 2016). On the other hand, a large-scale study of diffuse large B-cell lymphoma (DLBCL) demonstrates that PTEN dysregulation at multiple levels correlates to poor prognosis of DLBCL patients (Wang et al. 2018), suggesting PTEN loss

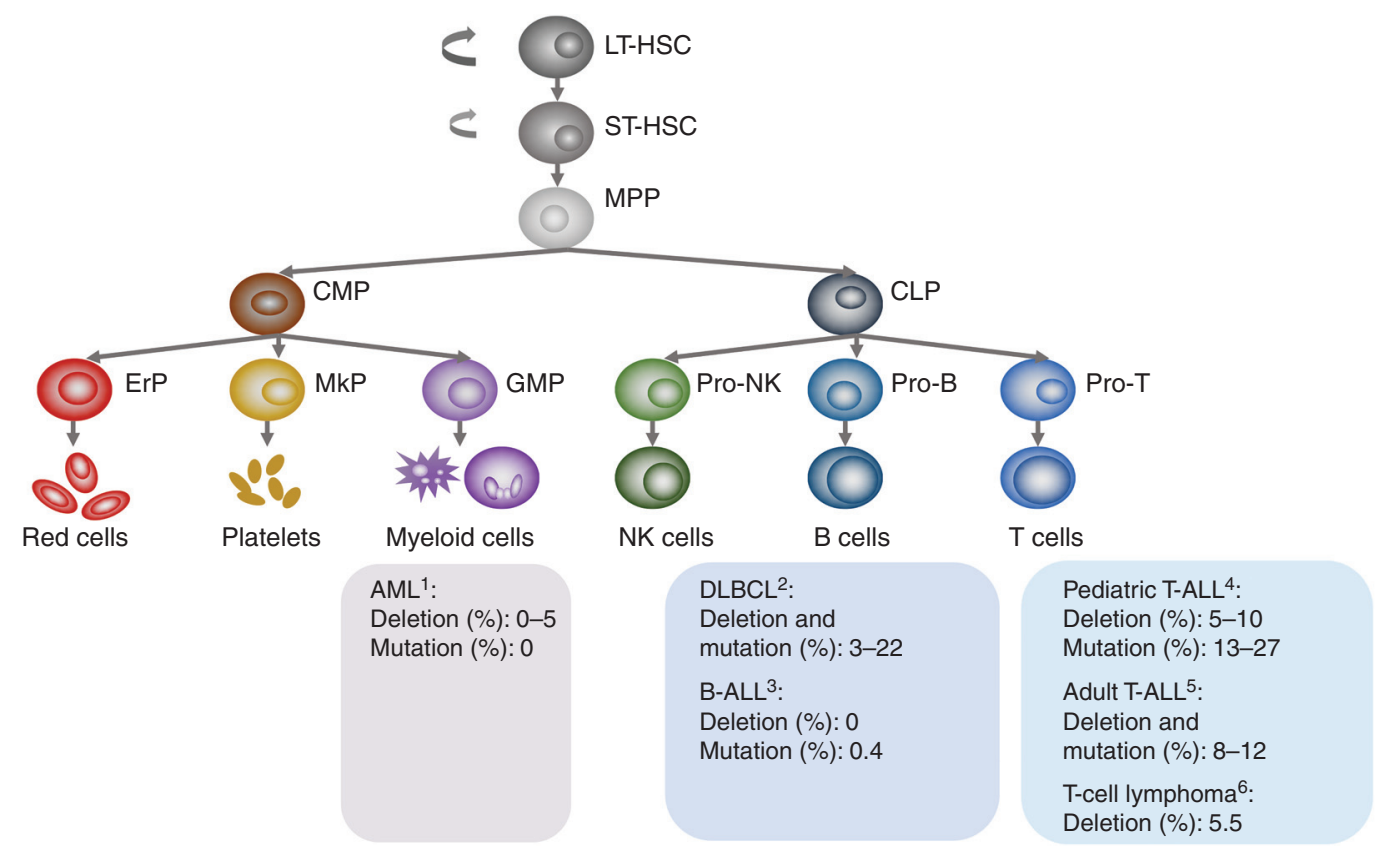

Figure 1. PTEN alterations in human leukemias and lymphomas. (AML) acute myeloid leukemia, (B-ALL) B-cell acute lymphoblastic leukemia, (DLBCL) diffuse large B-cell lymphoma, (T-ALL) T-cell acute lymphoblastic leukemia. ${ }^{1}$ Yoshida et al. (2011); Cancer Genome Atlas Research Network et al. (2013); Ma et al. (2018). ${ }^{2}$ Reddy et al. (2017); Wang et al. (2018). ${ }^{3} \mathrm{Ma}$ et al. (2018). ${ }^{4} \mathrm{Gutierrez}$ et al. (2009); Jenkinson et al. (2016); Liu et al. (2017); Ma et al. (2018). ${ }^{5}$ Trinquand et al. (2013); Neumann et al. (2014). ${ }^{6}$ Sondka et al. (2018). 
at different stages of B-cell development may result in different consequences.

The frequencies of PTEN mutation in T-ALL vary significantly in the earlier literature. Recent large-scale analyses revealed that $14 \%$ of pediatric and young adults (Liu et al. 2017) and $19 \%$ of pediatric T-ALL samples carried PTEN mutations (Seki et al. 2017). When combining data from all major papers, the frequency of PTEN mutations ranges from $8 \%$ to $12 \%$ in adults (Trinquand et al. 2013; Neumann et al. 2014 ) and $13 \%$ to $27 \%$ in pediatric T-ALLs (Fig. 1; Gutierrez et al. 2009; Zuurbier et al. 2012; Balbach et al. 2016; Jenkinson et al. 2016; Liu et al. 2017; Seki et al. 2017).

PTEN somatic mutations in T-ALL are concentrated in exon 7, different from exon 5 found in solid cancers (Fig. 2; Zuurbier et al. 2012; Jenkinson et al. 2016; Tesio et al. 2016; Liu et al. 2017). The exon 5 encodes the phosphatase domain and most mutations in the exon 5 lack phosphatase activity. The exon 7, on the other hand, encodes part of the C2-domain, which is important for lipid membrane binding, p53, and cell-migration regulations (Georgescu et al. 2000; Freeman et al. 2003; Raftopoulou et al. 2004), suggesting that a phosphataseindependent mechanism may be involved in PTEN-regulated leukemogenesis.

Besides genomic alterations, transcription, posttranscription, and posttranslation mechanisms can also lead to PTEN loss of function (Salmena et al. 2008). Alterations in the components of PI3K/AKT signaling pathway are also observed in T-ALL, especially in the pediatric TALL. Approximately $29 \%-88 \%$ of human pediatric T-ALL patients have hyperactivated PI3K/ AKT pathways, which could be the result of PTEN, PIK3R1, and AKT1 mutations (Silva et al. 2008; Gutierrez et al. 2009; Liu et al. 2017).

\section{Pten-Null Mouse Models for Human Leukemia and Lymphomas}

To understand the molecular and cellular mechanisms underlying PTEN-regulated leukemia and lymphoma development, a series of mouse models have been generated. Similar to high frequent PTEN mutations found in human T-ALL and T-cell lymphomas, the most prevalent phenotypes associated with Pten HSC and hematopoietic lineage-specific deletions are T-ALL and T-cell lymphomas (Table 1; Fig. 1).

VE-Cad-Cre-mediated Pten deletion in fetal liver HSCs leads to T-ALL but not leukemia in other lineages (Guo et al. 2008, 2011). PTEN loss, $\beta$-catenin activation, and $T c r \alpha / \delta$ - $c$ $M y c$ translocation-mediated T-cell-specific $M y c$ overexpression are three essential events, which are also found in human T-ALLs (Guo et al. 2008, 2011; Schubbert et al. 2014). Similarly, Vav-iCre-, Scl-Cre-, and Cd45-Cre-mediated Pten deletions in HSCs and $\mathrm{CD} 45^{+}$cells also lead to T-ALL development in adult mice without causing other types of leukemia (Tang et al. 2013; Tesio et al. 2013; Mirantes et al. 2016). pIpC-induced and Mx1-Cre-mediated Pten adult HSC deletion can cause both AML and T-ALL (Yilmaz et al. 2006; Zhang et al. 2006), which may be the result of PIpC-induced HSC activation or PTEN loss in non-HSC cells, as described in the previous section. Reactivation of PTEN via a tetracyclin-dependent system can reduce T-ALL dissemination but not leukemic burden in hematopoietic organs, suggesting that the role of PTEN in T-ALL may be dictated by the tissue microenvironment (Miething et al. 2014).

Pten deletion at different stages of T-cell development can also lead to T-cell lymphoma development (Table 1). Interestingly, Tcr $\alpha / \delta$ - $\mathcal{c}$ $M y c$ translocation has also been observed in Pten-deficient T-cell lymphomas (Liu et al. 2010).

\section{PTEN Controls Leukemia Stem Cells}

Cancer stem cells (CSCs) are a rare subpopulation found in various cancers, including hematopoietic malignancies (Batlle and Clevers 2017). CSCs were first identified in AML patients (Bonnet and Dick 1997), and were named leukemia-initiating cells (LICs) or LSCs. Analog to normal HSCs, LSCs have the ability of selfrenewal and differentiation (Reya et al. 2001). However, there are very few publications on the identity of human T-ALL LSCs (Cox et al. 2007; Chiu et al. 2010). 

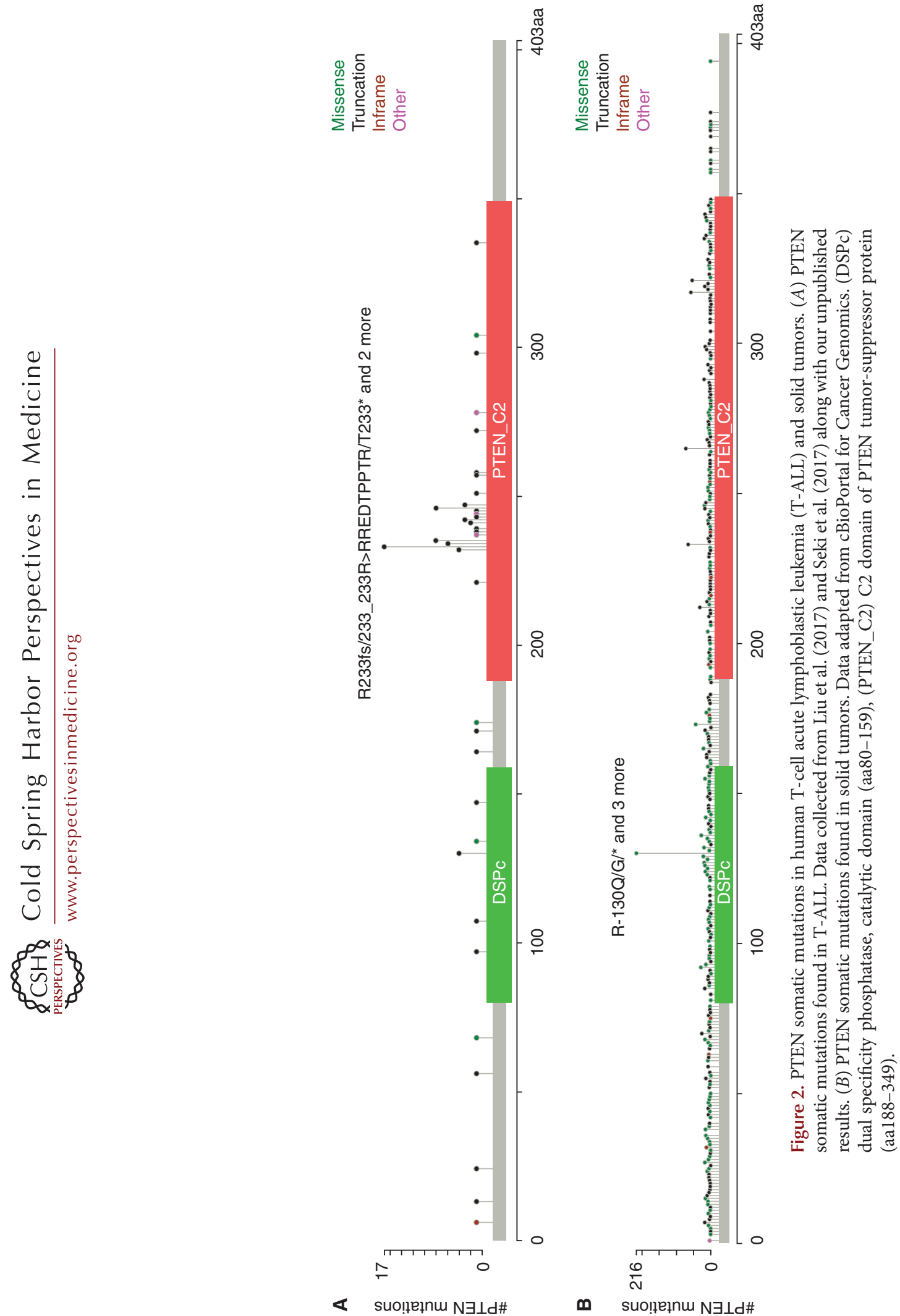
LSCs have been identified within the $\mathrm{Lin}^{-} \mathrm{CD} 3^{+} \mathrm{c}-\mathrm{kit}^{\mathrm{mid}} \mathrm{HAVCR} 2^{\text {high }}$ subpopulation in the VE-Cad-Cre; Pten ${ }^{L / L}$ model (Guo et al. 2008; Zhu et al. 2018). Pten deletion, $\beta$-catenin activation, and Tcr $\alpha / \delta$-Myc translocation, the aforementioned three events essential for $\mathrm{T}$ ALL development, are also important for LSC formation (Guo et al. 2008, 2011; Schubbert et al. 2014). Genetic deletion of $\beta$-catenin in the Pten-null T-ALL model can block LSC formation and T-ALL development (Guo et al. 2008). T-ALL initiated by $\beta$-catenin activation also has Tcr $\alpha / \delta$-Myc translocation and Pten deletion (Kaveri et al. 2013; Dose et al. 2014), indicating that the presence of the three essential events, rather than the order of the events, are important for LSC formation. LSC formation is recombinase-activating gene (RAG)-dependent as deletion of RAG1 in the Pten-null TALL mice can prevent Tcr $\alpha / \delta$-Myc translocation and T-ALL development (Liu et al. 2010; Guo et al. 2011). Rapamycin, a specific inhibitor of the mTOR pathway, can mimic Rag1 deletion in suppressing LSC formation and T-ALL development at the initial stage of T-ALL development (Guo et al. 2011).

The maintenance of Pten-null LSC "stemness," however, requires another layer of a control mechanism, that is, by the master regulator SPI1 and the $\beta$-catenin-SPI1-HAVCR2 regulatory circuit (Zhu et al. 2018). SPI1 is an ETS domain transcription factor, which is essential for LSC-signature gene expression and LSC activity. Deletion of Spi1 in the Pten-null T-ALL model can completely block LSC formation. Although initiated by PI3K-controlled $\beta$-catenin activation, the LSC-specific expression of Spi1 is reinforced by the $\beta$-catenin-SPI1-HAVCR2 regulatory circuit. Once formed, LSCs are very sensitive to any perturbation of this regulatory circuit, either genetically or pharmacologically, but less dependent on its driver mutations, as inhibiting a PTEN-controlled PI3K pathway at the leukemia stage has little effect on LSC number and T-ALL development (Guo et al. 2011; Schubbert et al. 2014; Zhu et al. 2018). Spi1 is silenced by DNA methylation, which leads to shut down of LSC-signature gene expressions, loss of LSC "stemness," and leukemic differen- tiation, suggesting that LSC "stemness" maintenance is reversibly controlled by an epigenetic mechanism. Whether human T-ALL LSCs are also regulated a similar mechanism remains to be seen but translocation-mediated SPI1 overexpression has been identified recently in highrisk pediatric T-ALL patients (Seki et al. 2017; Chen et al. 2018).

\section{Targeting PTEN-Null Leukemias and Lymphomas}

PTEN mutation or constitutive activation of its downstream PI3K/AKT/mTOR signaling pathway are common events in human T-ALL and lymphomas, suggesting PI3K could be an effective target for treating PTEN-deficient leukemias and lymphomas. The PI3K inhibitors LY294002, wortmannin and BAY1082439 (Hagenbeek et al. 2014; Zhu et al. 2018), AKT inhibitor triciribine (Evangelisti et al. 2011), and mTOR inhibitors Rapamycin and pp242 (Guo et al. 2011; Schubbert et al. 2014; Kawata et al. 2018; Zhu et al. 2018) can efficiently suppress TALL cell growth either in vitro in cell lines or in vivo in the mouse models. The class I PI3K is comprised of $\alpha$-, $\beta$-, $\gamma$ - and $\delta$ - isoforms, and each has different biological functions in human cancers (Katso et al. 2001). Both p110 $\gamma$ and p110 are required for Pten-null T-ALL development, and inhibiting the catalytic domains of p110 $\gamma$ and $\mathrm{p} 110 \delta$ by a novel small molecular CAL130 can induce cell apoptosis in vitro and reduce the disease burden in vivo in a Pten-deficient TALL model (Subramaniam et al. 2012).

However, the pharmacological inhibitors of the PI3K/AKT/mTOR pathway could inhibit some but not all PTEN-null human T-ALL cell lines in vitro, and blasts but not LSCs in the Pten-null mice model in vivo (Guo et al. 2011; Schubbert et al. 2014; Zhu et al. 2018), suggesting that other survival mechanisms may contribute to the drug resistance in the PTEN-null T-ALL. Dysregulated NOTCH signaling pathway is one of the most prevalent events found in human T-ALL. The NOTCH1 signaling pathway cross talks to the PI3K/AKT pathway and loss of PTEN function makes T-ALL cell lines resistant to NOTCH1 $\gamma$-secretase inhibitors 
Y. Wu et al.

(GSIs) (Palomero et al. 2007). Further studies demonstrated that NOTCH represses PTEN expression through NOTCH1-HES1-mediated mechanisms (Palomero et al. 2007). In PTENdeficient T-ALL without NOTCH pathway mutations, the DLL4/NOTCH signal plays an independent and nonredundant role (Hagenbeek et al. 2014). Similarly, a recent study shows that focal adhesion kinase (FAK) provides a parallel pathway to the PI3K/AKT/mTOR pathway, and blocking FAK signaling makes Pten-null TALL cells sensitive to PI3K/AKT inhibitors (You et al. 2015).

CSCs are considered as the root of the cancer and are responsible for cancer propagation and therapeutic resistance (Dean et al. 2005). Although T-ALL blast cells are very sensitive to PI3K inhibitors, LSCs are resistant to such treatments because of their dependency on the $\beta$ catenin-SPI1-HAVCR2 regulatory circuit (Guo et al. 2011; Schubbert et al. 2014; Zhu et al. 2018). Perturbation of this regulatory circuit by WNT/ $\beta$-catenin inhibitors BAY6060/6167, SPI1 inhibitor DB1976, or HAVCR2 antibody, in combination with PI3K/AKT inhibitors rapamycin or BAY1082439, can eradicate both LSCs and T-ALL blast cells in Pten-null T-ALL, suggesting that the effective treatments for PTENnull T-ALL need to cotarget both oncogenic driver mutations and "stemness" maintenance pathways (Zhu et al. 2018).

Other therapeutic strategies are also worth exploring, including metabolic therapies and immunotherapies. The PTEN/PI3K/AKT pathway plays a key role in regulating cell metabolic pathways by promoting aerobic glycolysis and protein synthesis. Deletion of $S 6 k 1$, a downstream target of mTORC1, can significantly delay leukemia development in the Pten deficiency model (Tandon et al. 2011). NOTCH activation can promote glycolysis and glutamine oxidation through PI3K and MYC activation, which induces metabolic stress and activates AMPK. AMPK is essential to balance glycolysis and mitochondria function to control T-ALL cell stress and survival, and AMPK deficiency leads to TALL cell death and reduced disease burden (Herranz et al. 2015; Kishton et al. 2016). The PTEN or PI3K pathway also regulates cancer metabolic reprogramming by diverging glycolytic intermediates to branching metabolic pathways, such as PPP and HBP, and PTEN-null T-ALL cell lines and in vivo mouse model are also very sensitive to the PPP or HBP inhibition (unpubl.).

CAR-T-mediated immunotherapy is very effective in treating B-ALL (June et al. 2018). As a highly heterogeneous disease with different cell-surface marker expressions, recent studies have identified differential expressions of CD5, CD7, and T-cell receptor (TCR) in different subtypes of T-ALLs (Chen et al. 2017; Gomes-Silva et al. 2017; Maciocia et al. 2017; Cooper et al 2018). However, systematic efforts are needed to identify the immunotherapy targets specific for PTEN-deficient T-ALLs.

\section{PROSPECTIVE}

After two decades of investigations, the essential roles of PTEN in regulating HSC maintenance, lineage commitment, and leukemogenesis have been well established. However, some of the important mechanisms are still lacking and translation of the promising preclinical results to patient treatments requires a joint effort among basic and clinical scientists, as well as pharmaceutical companies. Some important research areas are listed below:

1. Study PTEN-controlled hematopoiesis and leukemogenesis under homeostatic conditions. Recent studies, based on single-cell omics and lineage tracing under steady-state conditions, have redefined the hematopoietic hierarchy. Instead of a stepwise discrete process, previously defined HSCs and progenitors, are now been recognized as heterogeneous cell populations, plastic and lacking obvious boundaries (Macaulay et al. 2016; Velten et al. 2017; Buenrostro et al. 2018; Karamitros et al. 2018). Because previous studies are largely based on transplantation of FACS sorted donor cells to irradiated immune-incompetent recipients, how PTEN regulates HSCs in its native niche and in a steady-state setting requires further investigation. 
Studying the function of Pten-null HSCs in its native niche will also help us understand the role of PTEN in regulating HSC lineage commitment. Pten deletion in HSCs leads to increased myeloid and $\mathrm{T}$ lineages, accompanied by arrested B-cell development (Zhang et al. 2006; Guo et al. 2008). Based on the new view of a hematopoietic hierarchy, these seemingly disconnected events may be intrinsically linked in progenitor(s) that can switch among different lineages. The underlying mechanism may also shed light on certain mixed-lineage phenotypes associated with human leukemia (Gutierrez and Kentsis 2018).

2. Investigate the role of PTEN in regulating the epigenetic landscape during hematopoiesis and leukemogenesis. Despite the similarity in their gene expression patterns, each HSC clone has its distinct chromatin architecture, leading to functionally distinct lineage preference (Yu et al. 2016). The impacts of epigenetic regulations on hematopoiesis and leukemogenesis are also reflected by the identification of DNMT3A, ASXL1, TET2, and IDH1/IDH2 mutations that correlate with a predisposition to hematopoietic malignancies (González et al. 2015; Corces et al. 2016; Langstein et al. 2018). Given the roles of PTEN in controlling HSC lineage commitment and leukemogenesis, investigating whether and how PTEN regulates the hematopoietic and leukemic epigenetic landscape will be important.

3. Target the key leukemia driver transcription factors. Transcription factors play essential roles in lineage choice during hematopoiesis, and their alterations can drive hematopoietic malignancies. Transcription factors are usually regarded as undruggable targets and JQ1 is the first small molecule inhibitor that can effectively inhibit the BRD4 transcription factor (Filippakopoulos et al. 2010). BRD4 is known to drive $c-M y c$ expression (Zuber et al. 2011) and JQ1 has been used to target MYC-dependent AML, ALL, and other cancer types (Delmore et al. 2011; Mertz et al. 2011; Ott et al. 2012). PTEN-null T-ALLs with $T c r \alpha / \delta$-c-Myc translocation are also sensitive to JQ1 (Schubbert et al. 2014). DB1976 is another small-molecule inhibitor that can specifically block the interaction between SPI1 and its target DNA sequences (Munde et al. 2014; Stephens et al. 2016). DB1976 has therapeutic effects on PTEN-null T-ALL and tissue fibrosis, of which SPI1 has been identified as the master regulator (Zhu et al. 2018; Wohlfahrt et al. 2019). Therefore, developing clinical grade small molecular inhibitors that can directly target c-MYC and other cancerdriving transcription factors will open new windows for leukemia treatment.

4. Cotarget both cancer driver mutations and CSC maintenance mechanisms. The discovery of LSC maintenance mechanisms, independent of the cancer driver mutations in the Pten-null T-ALL model (Zhu et al. 2018), may have more general and important implications for treating cancers in which CSCs are known to play essential roles. First, targeting driver mutations or dysregulated pathways may be sufficient for debulking the tumor mass but not for eliminating CSCs unless the CSC "stemness" maintenance mechanism is simultaneously inhibited. Second, since the CSC "stemness" maintenance mechanisms are likely regulated by epigenetic mechanisms, one would predict poorer outcomes if cancers controlled by such a mechanism were treated by $5-\mathrm{AZ}$ or similar agents.

Collectively, what we have learned in the past two decades will pave new ways to study the role of PTEN in the hematopoietic system and open new windows to explore novel therapeutic strategies for treating hematological malignancies caused by PTEN loss.

\section{ACKNOWLEDGMENTS}

We appreciate members of our laboratory for their valuable comments and suggestions. This work was supported by Peking-Tsinghua Center for Life Sciences and Beijing Advanced Innovation Center for Genomics at Peking University to H.W. 
Y. Wu et al.

\section{REFERENCES}

Adolfsson J, Borge OJ, Bryder D, Theilgaard-Mönch K, Åstrand-Grundström I, Sitnicka E, Sasaki Y, Jacobsen SE 2001. Upregulation of Flt3 expression within the bone marrow $\mathrm{Lin}^{-} \mathrm{Scal}^{+}{ }^{\mathrm{c}-\mathrm{kit}^{+}}$stem cell compartment is accompanied by loss of self-renewal capacity. Immunity 15: 659-669. doi:10.1016/S1074-7613(01)00220-5

Adolfsson J, Månsson R, Buza-Vidas N, Hultquist A, Liuba $\mathrm{K}$, Jensen CT, Bryder D, Yang L, Borge OJ, Thoren LA, et al. 2005. Identification of $\mathrm{Flt}^{+}$lympho-myeloid stem cells lacking erythro-megakaryocytic potential a revised road map for adult blood lineage commitment. Cell 121: 295-306. doi:10.1016/j.cell.2005.02.013

Anzelon AN, Wu H, Rickert RC. 2003. Pten inactivation alters peripheral B lymphocyte fate and reconstitutes CD19 function. Nat Immunol 4: 287-294. doi:10.1038/ ni892

Bailey MH, Tokheim C, Porta-Pardo E, Sengupta S, Bertrand D, Weerasinghe A, Colaprico A, Wendl MC, Kim J, Reardon B, et al. 2018. Comprehensive characterization of cancer driver genes and mutations. Cell 173: 371-385. e18. doi:10.1016/j.cell.2018.02.060

Balbach ST, Makarova O, Bonn BR, Zimmermann M, Rohde M, Oschlies I, Klapper W, Rössig C, Burkhardt B. 2016. Proposal of a genetic classifier for risk group stratification in pediatric T-cell lymphoblastic lymphoma reveals differences from adult T-cell lymphoblastic leukemia. Leukemia 30: 970-973. doi:10.1038/leu.2015.203

Baldridge MT, King KY, Boles NC, Weksberg DC, Goodell MA. 2010. Quiescent haematopoietic stem cells are activated by IFN- $\gamma$ in response to chronic infection. Nature 465: 793-797. doi:10.1038/nature09135

Batlle E, Clevers H. 2017. Cancer stem cells revisited. Nat Med 23: 1124-1134. doi:10.1038/nm.4409

Becker AJ, McCulloch EA, Till JE. 1963. Cytological demonstration of the clonal nature of spleen colonies derived from transplanted mouse marrow cells. Nature 197: 452454. doi:10.1038/197452a0

Bonnet D, Dick JE. 1997. Human acute myeloid leukemia is organized as a hierarchy that originates from a primitive hematopoietic cell. Nat Med 3: 730-737. doi:10.1038/ nm0797-730

Boyer SW, Schroeder AV, Smith-Berdan S, Forsberg EC 2011. All hematopoietic cells develop from hematopoietic stem cells through Flk2/Flt3-positive progenitor cells. Cell Stem Cell 9: 64-73. doi:10.1016/j.stem.2011.04.021

Buenrostro JD, Corces MR, Lareau CA, Wu B, Schep AN, Aryee MJ, Majeti R, Chang HY, Greenleaf WJ. 2018. Integrated single-cell analysis maps the continuous regulatory landscape of human hematopoietic differentiation. Cell 173: 1535-1548.e16. doi:10.1016/j.cell.2018.03.074

Cancer Genome Atlas Research Network; Ley TJ, Miller C, Ding L, Raphael BJ, Mungall AJ, Robertson A, Hoadley K, Triche TJ Jr, Laird PW, et al. 2013. Genomic and epigenomic landscapes of adult de novo acute myeloid leukemia. N Engl J Med 368: 2059-2074.

Chen KH, Wada M, Pinz KG, Liu H, Lin KW, Jares A, Firor AE, Shuai X, Salman H, Golightly M, et al. 2017. Preclinical targeting of aggressive T-cell malignancies using antiCD5 chimeric antigen receptor. Leukemia 31: 2151-2160. doi:10.1038/leu.2017.8
Chen B, Jiang L, Zhong ML, Li JF, Li BS, Peng LJ, Dai YT, Cui BW, Yan TQ, Zhang WN, et al. 2018. Identification of fusion genes and characterization of transcriptome features in T-cell acute lymphoblastic leukemia. Proc Nat Acad Sci 115: 373-378. doi:10.1073/pnas.1717125115

Chiu PP, Jiang H, Dick JE. 2010. Leukemia-initiating cells in human T-lymphoblastic leukemia exhibit glucocorticoid resistance. Blood 116: 5268-5279. doi:10.1182/blood2010-06-292300

Christensen JL, Weissman IL. 2001. Flk-2 is a marker in hematopoietic stem cell differentiation: a simple method to isolate long-term stem cells. Proc Natl Acad Sci 98: 14541-14546. doi:10.1073/pnas.261562798

Cooper ML, Choi J, Staser K, Ritchey JK, Devenport JM, Eckardt K, Rettig MP, Wang B, Eissenberg LG, Ghobadi A, et al. 2018. An "off-the-shelf" fratricide-resistant CAR$\mathrm{T}$ for the treatment of $\mathrm{T}$ cell hematologic malignancies. Leukemia 32: 1970-1983. doi:10.1038/s41375-018-00 65-5

Corces MR, Buenrostro JD, Wu B, Greenside PG, Chan SM, Koenig JL, Snyder MP, Pritchard JK, Kundaje A, Greenleaf WJ, et al. 2016. Lineage-specific and single-cell chromatin accessibility charts human hematopoiesis and leukemia evolution. Nat Genet 48: 1193-1203. doi:10.1038/ ng.3646

Cox CV, Martin HM, Kearns PR, Virgo P, Evely RS, Blair A. 2007. Characterization of a progenitor cell population in childhood T-cell acute lymphoblastic leukemia. Blood 109: 674-682. doi:10.1182/blood-2006-06-030445

Dean M, Fojo T, Bates S. 2005. Tumour stem cells and drug resistance. Nat Rev Cancer 5: 275-284. doi:10.1038/ nrc1590

Delmore JE, Issa GC, Lemieux ME, Rahl PB, Shi J, Jacobs HM, Kastritis E, Gilpatrick T, Paranal RM, Qi J, et al. 2011. BET bromodomain inhibition as a therapeutic strategy to target c-Myc. Cell 146: 904-917. doi:10 $.1016 /$ j.cell.2011.08.017

Dengler HS, Baracho GV, Omori SA, Bruckner S, Arden KC, Castrillon DH, DePinho RA, Rickert RC. 2008. Distinct functions for the transcription factor Foxol at various stages of B cell differentiation. Nat Immunol 9: 13881398. doi:10.1038/ni.1667

Dose M, Emmanuel AO, Chaumeil J, Zhang J, Sun T, Germar K, Aghajani K, Davis EM, Keerthivasan S, Bredemeyer AL, et al. 2014. $\beta$-Catenin induces T-cell transformation by promoting genomic instability. Proc Natl Acad Sci 111: 391-396. doi:10.1073/pnas.1315752111

Essers MA, Offner S, Blanco-Bose WE, Waibler Z, Kalinke U, Duchosal MA, Trumpp A. 2009. IFN $\alpha$ activates dormant haematopoietic stem cells in vivo. Nature 458: 904908. doi:10.1038/nature07815

Evangelisti C, Ricci F, Tazzari P, Chiarini F, Battistelli M, Falcieri E, Ognibene A, Pagliaro P, Cocco L, McCubrey JA, et al. 2011. Preclinical testing of the Akt inhibitor triciribine in T-cell acute lymphoblastic leukemia. J Cell Physiol 226: 822-831. doi:10.1002/jcp.22407

Filippakopoulos P, Qi J, Picaud S, Shen Y, Smith WB, Fedorov O, Morse EM, Keates T, Hickman TT, Felletar I, et al. 2010. Selective inhibition of BET bromodomains. $\mathrm{Na}$ ture 468: 1067-1073. doi:10.1038/nature09504

Forsberg EC, Serwold T, Kogan S, Weissman IL, Passegué E. 2006. New evidence supporting megakaryocyte-erythro- 
cyte potential of $\mathrm{flk} 2 / \mathrm{flt}^{+}$multipotent hematopoietic progenitors. Cell 126: 415-426. doi:10.1016/j.cell.2006 .06 .037

Freeman DJ, Li AG, Wei G, Li HH, Kertesz N, Lesche R, Whale AD, Martinez-Diaz H, Rozengurt N, Cardiff RD, et al. 2003. PTEN tumor suppressor regulates $\mathrm{p} 53$ protein levels and activity through phosphatase-dependent and -independent mechanisms. Cancer Cell 3: 117-130. doi:10.1016/S1535-6108(03)00021-7

Freeman D, Lesche R, Kertesz N, Wang S, Li G, Gao J, Groszer M, Martinez-Diaz H, Rozengurt N, Thomas G, et al. 2006. Genetic background controls tumor development in Pten-deficient mice. Cancer Res 66: 6492-6496. doi:10.1158/0008-5472.CAN-05-4143

Fu CT, Zhu KY, Mi JQ, Liu YF, Murray ST, Fu YF, Ren CG, Dong ZW, Liu YJ, Dong M, et al. 2010. An evolutionarily conserved PTEN-C/EBP $\alpha$-CTNNA1 axis controls myeloid development and transformation. Blood 115: 47154724. doi:10.1182/blood-2009-11-255778

Georgescu M-M, Kirsch KH, Kaloudis P, Yang H, Pavletich NP, Hanafusa H. 2000. Stabilization and productive positioning roles of the $\mathrm{C} 2$ domain of PTEN tumor suppressor. Cancer Res 60: 7033-7038.

Gomes-Silva D, Srinivasan M, Sharma S, Lee CM, Wagner DL, Davis TH, Rouce RH, Bao G, Brenner MK, Mamonkin M. 2017. CD7-edited T cells expressing a CD7-specific CAR for the therapy of T-cell malignancies. Blood 130: 285-296. doi:10.1182/blood-2017-01-761320

González AJ, Setty M, Leslie CS. 2015. Early enhancer establishment and regulatory locus complexity shape transcriptional programs in hematopoietic differentiation. Nat Genet 47: 1249-1259. doi:10.1038/ng.3402

Groszer M, Erickson R, Scripture-Adams DD, Lesche R, Trumpp A, Zack JA, Kornblum HI, Liu X, Wu H. 2001. Negative regulation of neural stem/progenitor cell proliferation by the Pten tumor suppressor gene in vivo. Science 294: 2186-2189. doi:10.1126/science.1065518

Groszer M, Erickson R, Scripture-Adams DD, Dougherty JD, Le Belle J, Zack JA, Geschwind DH, Liu X, Kornblum HI, Wu H. 2006. PTEN negatively regulates neural stem cell self-renewal by modulating $\mathrm{G}_{0}-\mathrm{G}_{1}$ cell cycle entry. Proc Natl Acad Sci 103: 111-116. doi:10.1073/pnas .0509939103

Guertin DA, Sabatini DM. 2007. Defining the role of mTOR in cancer. Cancer Cell 12: 9-22. doi:10.1016/j.ccr.2007.05 .008

Guo W, Lasky JL, Chang CJ, Mosessian S, Lewis X, Xiao Y, Yeh JE, Chen JY, Iruela-Arispe ML, Varella-Garcia M, et al. 2008. Multi-genetic events collaboratively contribute to Pten-null leukaemia stem-cell formation. Nature 453: 529-533. doi:10.1038/nature06933

Guo W, Schubbert S, Chen JY, Valamehr B, Mosessian S, Shi H, Dang NH, Garcia C, Theodoro MF, Varella-Garcia M, et al. 2011. Suppression of leukemia development caused by PTEN loss. Proc Natl Acad Sci 108: 1409-1414. doi:10 $.1073 /$ pnas. 1006937108

Gutierrez A, Kentsis A. 2018. Acute myeloid/T-lymphoblastic leukaemia (AMTL): a distinct category of acute leukaemias with common pathogenesis in need of improved therapy. Br J Haematol 180: 919-924. doi:10.1111/bjh .15129
Gutierrez A, Sanda T, Grebliunaite R, Carracedo A, Salmena L, Ahn Y, Dahlberg S, Neuberg D, Moreau LA, Winter SS, et al. 2009. High frequency of PTEN, PI3K, and AKT abnormalities in T-cell acute lymphoblastic leukemia. Blood 114: 647-650. doi:10.1182/blood-2009-02-206722

Hagenbeek TJ, Spits H. 2008. T-cell lymphomas in T-cellspecific Pten-deficient mice originate in the thymus. Leukemia 22: 608-619. doi:10.1038/sj.leu.2405056

Hagenbeek TJ, Naspetti M, Malergue F, Garçon F, Nunès JA, Cleutjens KB, Trapman J, Krimpenfort P, Spits H. 2004. The loss of PTEN allows TCR $\alpha \beta$ lineage thymocytes to bypass IL-7 and Pre-TCR-mediated signaling. J Exp Med 200: 883-894. doi:10.1084/jem.20040495

Hagenbeek TJ, Wu X, Choy L, Sanchez-Irizarry C, Seshagiri S, Stinson J, Siebel CW, Spits H. 2014. Murine Pten ${ }^{-/-}$ T-ALL requires non-redundant PI3K/mTOR and DLL4/ Notch 1 signals for maintenance and $\gamma \mathrm{c} / \mathrm{TCR}$ signals for thymic exit. Cancer Lett 346: 237-248. doi:10.1016/j .canlet.2013.12.027

Herranz D, Ambesi-Impiombato A, Sudderth J, SánchezMartín M, Belver L, Tosello V, Xu L, Wendorff AA, Castillo M, Haydu JE, et al. 2015. Metabolic reprogramming induces resistance to anti-NOTCH1 therapies in T cell acute lymphoblastic leukemia. Nat Med 21: 1182-1189. doi:10.1038/nm.3955

Hollander MC, Blumenthal GM, Dennis PA. 2011. PTEN loss in the continuum of common cancers, rare syndromes and mouse models. Nat Rev Cancer 11: 289301. doi:10.1038/nrc3037

Jenkinson S, Kirkwood AA, Goulden N, Vora A, Linch DC, Gale RE. 2016. Impact of PTEN abnormalities on outcome in pediatric patients with T-cell acute lymphoblastic leukemia treated on the MRC UKALL2003 trial. Leukemia 30: 39-47. doi:10.1038/leu.2015.206

June CH, O'Connor RS, Kawalekar OU, Ghassemi S, Milone MC. 2018. CAR T cell immunotherapy for human cancer. Science 359: 1361-1365. doi:10.1126/science.aar6711

Kalaitzidis D, Sykes SM, Wang Z, Punt N, Tang Y, Ragu C, Sinha AU, Lane SW, Souza AL, Clish CB, et al. 2012. mTOR complex 1 plays critical roles in hematopoiesis and Pten-loss-evoked leukemogenesis. Cell Stem Cell 11: 429-439. doi:10.1016/j.stem.2012.06.009

Karamitros D, Stoilova B, Aboukhalil Z, Hamey F, Reinisch A, Samitsch M, Quek L, Otto G, Repapi E, Doondeea J, et al. 2018. Single-cell analysis reveals the continuum of human lympho-myeloid progenitor cells. Nat Immunol 19: 85-97. doi:10.1038/s41590-017-0001-2

Katso R, Okkenhaug K, Ahmadi K, White S, Timms J, Waterfield MD. 2001. Cellular function of phosphoinositide 3-kinases: implications for development, immunity, homeostasis, and cancer. Annu Rev Cell Dev Biol 17: 615675. doi:10.1146/annurev.cellbio.17.1.615

Kaveri D, Kastner P, Dembele D, Nerlov C, Chan S, Kirstetter P. 2013. $\beta$-Catenin activation synergizes with Pten loss and Myc overexpression in Notch-independent T-ALL. Blood 122: 694-704. doi:10.1182/blood-2012-12471904

Kawata T, Tada K, Kobayashi M, Sakamoto T, Takiuchi Y, Iwai F, Sakurada M, Hishizawa M, Shirakawa K, Shindo K, et al. 2018. Dual inhibition of the mTORC1 and mTORC2 signaling pathways is a promising therapeutic target for 
Y. Wu et al.

adult T-cell leukemia. Cancer Sci 109: 103-111. doi:10 $.1111 /$ cas.13431

Kishton RJ, Barnes CE, Nichols AG, Cohen S, Gerriets VA, Siska PJ, Macintyre AN, Goraksha-Hicks P, de Cubas AA Liu T, et al. 2016. AMPK is essential to balance glycolysis and mitochondrial metabolism to control T-ALL cell stress and survival. Cell Metab 23: 649-662. doi:10 .1016/j.cmet.2016.03.008

Kuroda S, Nishio M, Sasaki T, Horie Y, Kawahara K, Sasak M, Natsui M, Matozaki T, Tezuka H, Ohteki T, et al. 2008. Effective clearance of intracellular Leishmania major in vivo requires Pten in macrophages. Eur J Immunol 38: 1331-1340. doi:10.1002/eji.200737302

Langstein J, Milsom MD, Lipka DB. 2018. Impact of DNA methylation programming on normal and pre-leukemic hematopoiesis. Semin Cancer Biol 51: 89-100. doi:10 .1016/j.semcancer.2017.09.008

Lee JY, Nakada D, Yilmaz OH, Tothova Z, Joseph NM, Lim MS, Gilliland DG, Morrison SJ. 2010. mTOR activation induces tumor suppressors that inhibit leukemogenesis and deplete hematopoietic stem cells after Pten deletion. Cell Stem Cell 7: 593-605. doi:10.1016/j.stem.2010.09.015

Lesche R, Groszer M, Gao J, Wang Y, Messing A, Sun H, Liu $\mathrm{X}, \mathrm{Wu} \mathrm{H}$. 2002. Cre/loxP-mediated inactivation of the murine Pten tumor suppressor gene. Genesis 32: 148 149. doi:10.1002/gene.10036

Li DM, Sun H. 1997. TEP1, encoded by a candidate tumor suppressor locus, is a novel protein tyrosine phosphatase regulated by transforming growth factor $\beta$. Cancer Res $\mathbf{5 7}$ : 2124-2129.

Li J, Yen C, Liaw D, Podsypanina K, Bose S, Wang SI, Puc J, Miliaresis C, Rodgers L, McCombie R, et al. 1997. PTEN, a putative protein tyrosine phosphatase gene mutated in human brain, breast, and prostate cancer. Science 275: 1943-1947. doi:10.1126/science.275.5308.1943

Li J, Zhang J, Tang M, Xin J, Xu Y, Volk A, Hao C, Hu C, Sun J, Wei W, et al. 2016. Hematopoietic stem cell activity is regulated by Pten phosphorylation through a niche-dependent mechanism. Stem Cells 34: 2130-2144. doi:10 $.1002 /$ stem.2382

Liaw D, Marsh DJ, Li J, Dahia PL, Wang SI, Zheng Z, Bose S, Call KM, Tsou HC, Peacocke M, et al. 1997. Germline mutations of the PTEN gene in Cowden disease, an inherited breast and thyroid cancer syndrome. Nat Genet 16: 64-67. doi:10.1038/ng0597-64

Liu X, Karnell JL, Yin B, Zhang R, Zhang J, Li P, Choi Y, Maltzman JS, Pear WS, Bassing CH, et al. 2010. Distinct roles for PTEN in prevention of T cell lymphoma and autoimmunity in mice. J Clin Invest 120: 2497-2507. doi:10.1172/JCI42382

Liu Y, Easton J, Shao Y, Maciaszek J, Wang Z, Wilkinson MR McCastlain K, Edmonson M, Pounds SB, Shi L, et al 2017. The genomic landscape of pediatric and young adult T-lineage acute lymphoblastic leukemia. Nat Genet 49: 1211-1218. doi:10.1038/ng.3909

Ma X, Liu Y, Liu Y, Alexandrov LB, Edmonson MN, Gawad C, Zhou X, Li Y, Rusch MC, Easton J, et al. 2018. Pancancer genome and transcriptome analyses of 1,699 paediatric leukaemias and solid tumours. Nature 555: 371.

Macaulay IC, Svensson V, Labalette C, Ferreira L, Hamey F, Voet T, Teichmann SA, Cvejic A. 2016. Single-cell RNAsequencing reveals a continuous spectrum of differentia- tion in hematopoietic cells. Cell Rep 14: 966-977. doi:10 .1016/j.celrep.2015.12.082

Maciocia PM, Wawrzyniecka PA, Philip B, Ricciardelli I, Akarca AU, Onuoha SC, Legut M, Cole DK, Sewell AK, Gritti G, et al. 2017. Targeting the T cell receptor $\beta$-chain constant region for immunotherapy of $\mathrm{T}$ cell malignancies. Nat Med 23: 1416-1423. doi:10.1038/nm.4444

Magee JA, Ikenoue T, Nakada D, Lee JY, Guan KL, Morrison SJ. 2012. Temporal changes in PTEN and mTORC2 regulation of hematopoietic stem cell self-renewal and leukemia suppression. Cell Stem Cell 11: 415-428. doi:10 .1016/j.stem.2012.05.026

Melchers F. 2015. Checkpoints that control B cell development. J Clin Invest 125: 2203-2210. doi:10.1172/JCI 78083

Mertz JA, Conery AR, Bryant BM, Sandy P, Balasubramanian S, Mele DA, Bergeron L, Sims RJ III. 2011. Targeting MYC dependence in cancer by inhibiting BET bromodomains. Proc Natl Acad Sci 108: 16669-16674. doi:10 $.1073 /$ pnas. 1108190108

Miething C, Scuoppo C, Bosbach B, Appelmann I, Nakitandwe J, Ma J, Wu G, Lintault L, Auer M, Premsrirut PK, et al. 2014. PTEN action in leukaemia dictated by the tissue microenvironment. Nature 510: 402-406. doi:10 $.1038 /$ nature13239

Mirantes C, Dosil MA, Hills D, Yang J, Eritja N, Santacana M, Gatius S, Vilardell F, Medvinsky A, Matias-Guiu X, et al. 2016. Deletion of Pten in CD45-expressing cells leads to development of T-cell lymphoblastic lymphoma but not myeloid malignancies. Blood 127: 1907-1911. doi:10.1182/blood-2015-09-669036

Morrison SJ, Wandycz AM, Hemmati HD, Wright DE, Weissman IL. 1997. Identification of a lineage of multipotent hematopoietic progenitors. Development 124: 1929-1939.

Munde M, Wang S, Kumar A, Stephens CE, Farahat AA, Boykin DW, Wilson WD, Poon GM. 2014. Structure-dependent inhibition of the ETS-family transcription factor PU.1 by novel heterocyclic diamidines. Nucleic Acids Res 42: 1379-1390. doi:10.1093/nar/gkt955

Nelen MR, van Staveren WC, Peeters EA, Hassel MB, Gorlin RJ, Hamm H, Lindboe CF, Fryns JP, Sijmons RH, Woods DG, et al. 1997. Germline mutations in the PTEN/ $M M A C_{1}$ gene in patients with Cowden disease. Hum Mol Genet 6: 1383-1387. doi:10.1093/hmg/6.8.1383

Neumann M, Vosberg S, Schlee C, Heesch S, Schwartz S, Gökbuget N, Hoelzer D, Graf A, Krebs S, Bartram I, et al. 2014. Mutational spectrum of adult T-ALL. Oncotarget 6: 2754-2766.

Newton RH, Lu Y, Papa A, Whitcher GH, Kang YJ, Yan C, Pandolfi PP, Turka LA. 2015. Suppression of T-cell lymphomagenesis in mice requires PTEN phosphatase activity. Blood 125: 852-855. doi:10.1182/blood-2014-04571372

Osawa M, Hanada K, Hamada H, Nakauchi H. 1996. Longterm lymphohematopoietic reconstitution by a single CD34-low/negative hematopoietic stem cell. Science 273: 242-245. doi:10.1126/science.273.5272.242

Ott CJ, Kopp N, Bird L, Paranal RM, Qi J, Bowman T, Rodig SJ, Kung AL, Bradner JE, Weinstock DM. 2012. BET bromodomain inhibition targets both c-Myc and IL7R in 
high-risk acute lymphoblastic leukemia. Blood 120: 2843-2852. doi:10.1182/blood-2012-02-413021

Palomero T, Sulis ML, Cortina M, Real PJ, Barnes K, Ciofani M, Caparros E, Buteau J, Brown K, Perkins SL, et al. 2007. Mutational loss of PTEN induces resistance to NOTCH1 inhibition in T-cell leukemia. Nat Med 13: 1203-1210. doi:10.1038/nm1636

Porter SN, Cluster AS, Signer RAJ, Voigtmann J, Monlish DA, Schuettpelz LG, Magee JA. 2016. Pten cell autonomously modulates the hematopoietic stem cell response to inflammatory cytokines. Stem Cell Reports 6: 806-814. doi:10.1016/j.stemcr.2016.04.008

Raftopoulou M, Etienne-Manneville S, Self A, Nicholls S, Hall A. 2004. Regulation of cell migration by the C2 domain of the tumor suppressor PTEN. Science 303: 11791181. doi:10.1126/science.1092089

Reddy A, Zhang J, Davis NS, Moffitt AB, Love CL, Waldrop A, Leppa S, Pasanen A, Meriranta L, Karjalainen-Lindsberg M-L, et al. 2017. Genetic and functional drivers of diffuse large B cell lymphoma. Cell 171: 481-494.e415.

Reya T, Morrison SJ, Clarke MF, Weissman IL. 2001. Stem cells, cancer, and cancer stem cells. Nature 414: 105-111. doi:10.1038/35102167

Rothenberg EV, Kueh HY, Yui MA, Zhang JA. 2016. Hematopoiesis and T-cell specification as a model developmental system. Immunol Rev 271: 72-97. doi:10.1111/imr .12417

Salmena L, Carracedo A, Pandolfi PP. 2008. Tenets of PTEN tumor suppression. Cell 133: 403-414. doi:10.1016/j.cell .2008 .04 .013

Sarraj B, Massberg S, Li Y, Kasorn A, Subramanian K, Loison F, Silberstein LE, von Andrian U, Luo HR. 2009. Myeloidspecific deletion of tumor suppressor PTEN augments neutrophil transendothelial migration during inflammation. J Immunol 182: 7190-7200. doi:10.4049/jimmunol .0802562

Schubbert S, Cardenas A, Chen H, Garcia C, Guo W, Bradner J, Wu H. 2014. Targeting the MYC and PI3K pathways eliminates leukemia-initiating cells in T-cell acute lymphoblastic leukemia. Cancer Res 74: 7048-7059. doi:10.1158/0008-5472.CAN-14-1470

Seki M, Kimura S, Isobe T, Yoshida K, Ueno H, NakajimaTakagi Y, Wang C, Lin L, Kon A, Suzuki H, et al. 2017. Recurrent SPI1 (PU.1) fusions in high-risk pediatric T cell acute lymphoblastic leukemia. Nat Genet 49: 1274-1281. doi:10.1038/ng. 3900

Shojaee S, Chan LN, Buchner M, Cazzaniga V, Cosgun KN Geng H, Qiu YH, von Minden MD, Ernst T, Hochhaus A, et al. 2016. PTEN opposes negative selection and enables oncogenic transformation of pre-B cells. Nat Med 22: 379-387. doi:10.1038/nm.4062

Signer RA, Magee JA, Salic A, Morrison SJ. 2014. Haematopoietic stem cells require a highly regulated protein synthesis rate. Nature 509: 49-54. doi:10.1038/nature13035

Silva A, Yunes JA, Cardoso BA, Martins LR, Jotta PY, Abecasis M, Nowill AE, Leslie NR, Cardoso AA, Barata JT. 2008. PTEN posttranslational inactivation and hyperactivation of the PI3K/Akt pathway sustain primary T cell leukemia viability. J Clin Invest 118: 3762-3774. doi:10 $.1172 /$ JCI34616
Smith LG, Weissman IL, Heimfeld S. 1991. Clonal analysis of hematopoietic stem-cell differentiation in vivo. Proc Natl Acad Sci 88: 2788-2792. doi:10.1073/pnas.88.7.2788

Sondka Z, Bamford S, Cole CG, Ward SA, Dunham I, Forbes SA. 2018. The COSMIC Cancer Gene Census: describing genetic dysfunction across all human cancers. Nat Rev Cancer 18: 696-705.

Song MS, Salmena L, Pandolfi PP. 2012. The functions and regulation of the PTEN tumour suppressor. Nat Rev Mol Cell Biol 13: 283-296. doi:10.1038/nrm3330

Steck PA, Pershouse MA, Jasser SA, Yung WK, Lin H, Ligon AH, Langford LA, Baumgard ML, Hattier T, Davis T, et al. 1997. Identification of a candidate tumour suppressor gene, MMAC1, at chromosome 10q23.3 that is mutated in multiple advanced cancers. Nat Genet 15: 356-362. doi:10.1038/ng0497-356

Stephens DC, Kim HM, Kumar A, Farahat AA, Boykin DW, Poon GM. 2016. Pharmacologic efficacy of PU.1 inhibition by heterocyclic dications: a mechanistic analysis. $\mathrm{Nu}$ cleic Acids Res 44: 4005-4013. doi:10.1093/nar/gkw229

Stiles B, Wang Y, Stahl A, Bassilian S, Lee WP, Kim YJ, Sherwin R, Devaskar S, Lesche R, Magnuson MA, et al. 2004. Liver-specific deletion of negative regulator Pten results in fatty liver and insulin hypersensitivity. Proc Natl Acad Sci 101: 2082-2087. doi:10.1073/pnas.030 8617100

Subramaniam PS, Whye DW, Efimenko E, Chen J, Tosello V, De Keersmaecker K, Kashishian A, Thompson MA, Castillo M, Cordon-Cardo C, et al. 2012. Targeting nonclassical oncogenes for therapy in T-ALL. Cancer Cell 21: 459-472. doi:10.1016/j.ccr.2012.02.029

Suzuki A, Yamaguchi MT, Ohteki T, Sasaki T, Kaisho T, Kimura Y, Yoshida R, Wakeham A, Higuchi T, Fukumoto $\mathrm{M}$, et al. 2001. T cell-specific loss of Pten leads to defects in central and peripheral tolerance. Immunity 14: 523-534. doi:10.1016/S1074-7613(01)00134-0

Suzuki A, Kaisho T, Ohishi M, Tsukio-Yamaguchi M, Tsubata T, Koni PA, Sasaki T, Mak TW, Nakano T. 2003 Critical roles of Pten in B cell homeostasis and immunoglobulin class switch recombination. J Exp Med 197: 657667. doi:10.1084/jem.20021101

Takizawa H, Boettcher S, Manz MG. 2012. Demand-adapted regulation of early hematopoiesis in infection and inflammation. Blood 119: 2991-3002. doi:10.1182/blood-201112-380113

Tandon P, Gallo CA, Khatri S, Barger JF, Yepiskoposyan H, Plas DR. 2011. Requirement for ribosomal protein S6 kinase 1 to mediate glycolysis and apoptosis resistance induced by Pten deficiency. Proc Natl Acad Sci 108: 2361-2365. doi:10.1073/pnas.1013629108

Tang P, Gao C, Li A, Aster J, Sun L, Chai L. 2013. Differential roles of Kras and Pten in murine leukemogenesis. Leukemia 27: 1210-1214. doi:10.1038/leu.2012.316

Tesio M, Oser GM, Baccelli I, Blanco-Bose W, Wu H, Göthert JR, Kogan SC, Trumpp A. 2013. Pten loss in the bone marrow leads to G-CSF-mediated HSC mobilization. J Exp Med 210: 2337-2349. doi:10.1084/jem.20122768

Tesio M, Trinquand A, Macintyre E, Asnafi V. 2016. Oncogenic PTEN functions and models in T-cell malignancies. Oncogene 35: 3887-3896. doi:10.1038/onc.2015.462 
Y. Wu et al.

Till JE, McCulloch EA. 1961. A direct measurement of the radiation sensitivity of normal mouse bone marrow cells. Radiat Res 14: 213-222. doi:10.2307/3570892

Tothova Z, Kollipara R, Huntly BJ, Lee BH, Castrillon DH, Cullen DE, McDowell EP, Lazo-Kallanian S, Williams IR, Sears C, et al. 2007. FoxOs are critical mediators of hematopoietic stem cell resistance to physiologic oxidative stress. Cell 128: 325-339. doi:10.1016/j.cell.2007.01.003

Trinquand A, Tanguy-Schmidt A, Ben Abdelali R, Lambert J, Beldjord K, Lengliné E, De Gunzburg N, Payet-Bornet D, Lhermitte L, Mossafa H, et al. 2013. Toward a NOTCH1/FBXW7/RAS/PTEN-based oncogenetic risk classification of adult T-cell acute lymphoblastic leukemia: a group for research in adult acute lymphoblastic leukemia study. J Clin Oncol 31: 4333-4342. doi:10 $.1200 / J C O .2012 .48 .5292$

Velten L, Haas SF, Raffel S, Blaszkiewicz S, Islam S, Hennig BP, Hirche C, Lutz C, Buss EC, Nowak D, et al. 2017. Human haematopoietic stem cell lineage commitment is a continuous process. Nat Cell Biol 19: 271-281. doi: $10.1038 /$ ncb3493

Verbiest T, Bouffler S, Nutt SL, Badie C. 2015. PU.1 downregulation in murine radiation-induced acute myeloid leukaemia (AML): from molecular mechanism to human AML. Carcinogenesis 36: 413-419. doi:10.1093/carcin/ bgv016

Wang X, Cao X, Sun R, Tang C, Tzankov A, Zhang J, Manyam GC, Xiao M, Miao Y, Jabbar K, et al. 2018. Clinical significance of PTEN deletion, mutation, and loss of PTEN expression in de novo diffuse large B-cell lymphoma. Neoplasia 20: 574-593. doi:10.1016/j.neo 2018.03.002

Weissman IL. 2000. Stem cells: units of development, units of regeneration, and units in evolution. Cell 100: 157-168. doi:10.1016/S0092-8674(00)81692-X

Weissman IL, Anderson DJ, Gage F. 2001. Stem and progenitor cells: origins, phenotypes, lineage commitments, and transdifferentiations. Annu Rev Cell Dev Biol 17: 387-403. doi:10.1146/annurev.cellbio.17.1.387

Wilson A, Laurenti E, Oser G, van der Wath RC, BlancoBose W, Jaworski M, Offner S, Dunant CF, Eshkind L, Bockamp E, et al. 2008. Hematopoietic stem cells reversibly switch from dormancy to self-renewal during homeostasis and repair. Cell 135: 1118-1129. doi:10.1016/j.cell 2008.10.048

Wohlfahrt T, Rauber S, Uebe S, Luber M, Soare A, Ekici A, Weber S, Matei AE, Chen CW, Maier C, et al. 2019. PU.1 controls fibroblast polarization and tissue fibrosis. Nature 566: 344-349. doi:10.1038/s41586-019-0896-x

Worby CA, Dixon JE. 2014. Unpacking the unfolded protein response. Cell 158: 1221-1224. doi:10.1016/j.cell.2014.08 .025

Xue L, Nolla H, Suzuki A, Mak TW, Winoto A. 2008. Normal development is an integral part of tumorigenesis in $\mathrm{T}$ cell-specific PTEN-deficient mice. Proc Natl Acad Sci 105: 2022-2027. doi:10.1073/pnas.0712059105

Yang L, Bryder D, Adolfsson J, Nygren J, Månsson R, Sigvardsson M, Jacobsen SE. 2005. Identification of $\mathrm{Lin}^{-} \mathrm{Sca}{ }^{+} \mathrm{kit}^{+} \mathrm{CD} 34^{+} \mathrm{Flt} 3^{-}$short-term hematopoietic stem cells capable of rapidly reconstituting and rescuing myeloablated transplant recipients. Blood 105: $2717-$ 2723. doi:10.1182/blood-2004-06-2159

Yilmaz OH, Valdez R, Theisen BK, Guo W, Ferguson DO, $\mathrm{Wu} \mathrm{H}$, Morrison SJ. 2006. Pten dependence distinguishes haematopoietic stem cells from leukaemia-initiating cells. Nature 441: 475-482. doi:10.1038/nature04703

Yoshida K, Sanada M, Shiraishi Y, Nowak D, Nagata Y, Yamamoto R, Sato Y, Sato-Otsubo A, Kon A, Nagasaki $\mathrm{M}$, et al. 2011. Frequent pathway mutations of splicing machinery in myelodysplasia. Nature 478: 64 .

You D, Xin J, Volk A, Wei W, Schmidt R, Scurti G, Nand S, Breuer EK, Kuo PC, Breslin P, et al. 2015. FAK mediates a compensatory survival signal parallel to PI3K-AKT in PTEN-null T-ALL cells. Cell Rep 10: 2055-2068. doi:10 .1016/j.celrep.2015.02.056

Yu VWC, Yusuf RZ, Oki T, Wu J, Saez B, Wang X, Cook C, Baryawno N, Ziller MJ, Lee E, et al. 2016. Epigenetic memory underlies cell-autonomous heterogeneous behavior of hematopoietic stem cells. Cell 167: 1310-1322. e17. doi:10.1016/j.cell.2016.10.045

Zhang J, Grindley JC, Yin T, Jayasinghe S, He XC, Ross JT, Haug JS, Rupp D, Porter-Westpfahl KS, Wiedemann LM, et al. 2006. PTEN maintains haematopoietic stem cells and acts in lineage choice and leukaemia prevention. $\mathrm{Na}$ ture 441: 518-522. doi:10.1038/nature04747

Zhu D, Hattori H, Jo H, Jia Y, Subramanian KK, Loison F, You J, Le Y, Honczarenko M, Silberstein L, et al. 2006. Deactivation of phosphatidylinositol 3,4,5-trisphosphate/ Akt signaling mediates neutrophil spontaneous death. Proc Natl Acad Sci 103: 14836-14841. doi:10.1073/pnas .0605722103

Zhu H, Zhang L, Wu Y, Dong B, Guo W, Wang M, Yang L, Fan X, Tang Y, Liu N, et al. 2018. T-ALL leukemia stem cell "stemness" is epigenetically controlled by the master regulator SPI1. eLife 7: e38314. doi:10.7554/eLife.38314

Zuber J, Shi J, Wang E, Rappaport AR, Herrmann H, Sison EA, Magoon D, Qi J, Blatt K, Wunderlich M, et al. 2011. RNAi screen identifies Brd4 as a therapeutic target in acute myeloid leukaemia. Nature 478: 524-528. doi:10 $.1038 /$ nature 10334

Zuurbier L, Petricoin EF III, Vuerhard MJ, Calvert V, Kooi C, Buijs-Gladdines JG, Smits WK, Sonneveld E, Veerman AJ, Kamps WA, et al. 2012. The significance of PTEN and AKT aberrations in pediatric T-cell acute lymphoblastic leukemia. Haematologica 97: 1405-1413. doi:10.3324/ haematol.2011.059030 


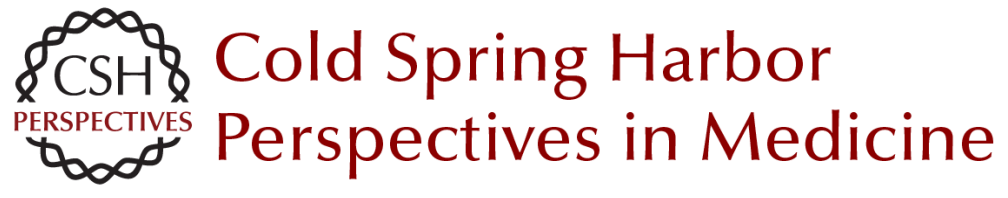

\section{PTEN in Regulating Hematopoiesis and Leukemogenesis}

Yilin Wu, Haichuan Zhu and Hong Wu

Cold Spring Harb Perspect Med 2020; doi: 10.1101/cshperspect.a036244 originally published online November 11, 2019

\section{Subject Collection The PTEN Family}

PTEN in Regulating Hematopoiesis and Leukemogenesis

Yilin Wu, Haichuan Zhu and Hong Wu

Connecting Genotype with Behavioral Phenotype

in Mouse Models of Autism Associated with

PTEN Mutations

Amy E. Clipperton-Allen and Damon T. Page

Metabolic Role of PTEN in Insulin Signaling and

Resistance

Yu Zhe Li, Antonio Di Cristofano and Minna Woo

Posttranslational Regulation and Conformational

Plasticity of PTEN

Larissa Kotelevets, Barbara Trifault, Eric Chastre, et al.

Toward Systems Pathology for PTEN Diagnostics Nahal Haddadi, Glena Travis, Najah T. Nassif, et al.

PTEN in Hereditary and Sporadic Cancer Joanne Ngeow and Charis Eng

PTEN Mouse Models of Cancer Initiation and Progression Yu-Ru Lee and Pier Paolo Pandolfi

Dual-Specific Protein and Lipid Phosphatase

PTEN and Its Biological Functions

Taojian Tu, Jingyu Chen, Lulu Chen, et al.
PTEN: Bridging Endocytosis and Signaling Matthew F. Lee and Lloyd C. Trotman

PTEN as a Guardian of the Genome: Pathways and Targets

Xinyi Fan, Jeffrey Kraynak, Jonathan P.S. Knisely, et al.

Discovery of the PTEN Tumor Suppressor and Its

Connection to the PI3K and AKT Oncogenes Ramon Parsons

The Complex Landscape of PTEN mRNA

Regulation

Erin Sellars, Martino Gabra and Leonardo Salmena

PTEN Nuclear Functions Jason Ho, Edward S. Cruise, Ryan J.O. Dowling, et al.

Structural Mechanisms of PTEN Regulation Glenn R. Masson and Roger L. Williams

PTEN in Chromatin Remodeling Jingyi Yang and Yuxin Yin

The Role of PTEN in Innate and Adaptive Immunity

Henry Taylor, Arian D. J. Laurence and Holm H. Uhlig

For additional articles in this collection, see http://perspectivesinmedicine.cshlp.org/cgi/collection/ 